
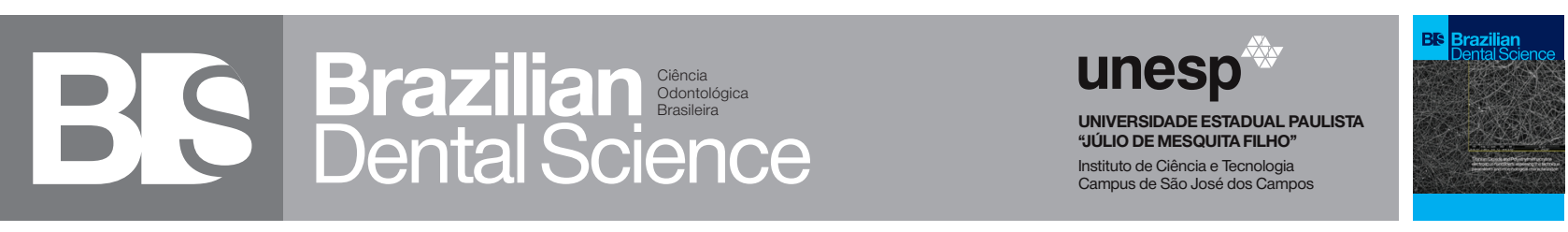

\title{
Microleakage of high viscosity glass-ionomer and glass-carbomer with and without coating before and after hydrothermal aging
}

Microinfiltracao de ionomero de vidro de alta viscosidade e carbômero de vidro com e sem revestimento antes e depois de envelhecimento hidrotermal

Aslı PATIR-MÜNEVVEROĞLU ${ }^{1}$, Alev ÖZSOY2, Beyza BALLI-AKGÖL ${ }^{1}$, Ruhan BOZATLIOĞLU1 ${ }^{1}$, Pelin KORKUT ${ }^{2}$, Büşra UYSAL ${ }^{1}$, Mutlu ÖZCAN $^{3}$

1 - Istanbul Medipol University - School of Dentistry - Department of Pedodontics - Istanbul - Turkey.

2 - Istanbul Medipol University - School of Dentistry - Department of Restorative Dentistry - Istanbul - Turkey.

3 - University of Zurich - Dental Materials Unit - Center for Dental and Oral Medicine - Clinic for Fixed and Removable Prosthodontics and Dental Materials Science - Zurich - Switzerland.

\section{ABSTRACT}

Objective: The objective of this study was to evaluate the microleakage patterns of GIC and GGC with and without their protective surface coatings on enamel and dentin margins before and after aging. Material and Methods: Two rectangular cavities (height: $2 \mathrm{~mm}$; width: 3 $\mathrm{mm}$; depth: $1.5 \mathrm{~mm}$ ) were prepared on each tooth at the cemento-enamel junction were prepared on human permanent molars $(\mathrm{N}=56)$ and the teeth were randomly assigned to be restored with one of the following: a) high viscosity glass-ionomer cement (GIC) (EQUIA Fil, C Corp., Tokyo, Japan) $(n=28)$, b) glasscarbomer cement (GCC) (Glass Carbomer Products, Leiden, The Netherlands) $(n=28)$. Half of the teeth were further divided into two groups where one group received protective surface coating (SC) (G-Coat Plus, GC Corp) $(n=14)$ and the other group did not $(n=14)$. Half of the teeth were stored for 24 hours $(n=7)$, and the other half was thermocycled (5000 cycles, $\left.5-55^{\circ} \mathrm{C}\right)(\mathrm{n}=7)$. For microleakage analysis, the teeth were immersed in 5\% methylene blue dye for 24 hours, sectioned into two equal halves. Microleakage patterns were evaluated using stereomicroscope and scored on a scale of 0-3 (0: No dye penetration, 1: Dye penetration less than half of the axial wall, 2: Dye penetration more than half the axial wall, 3: Dye penetration spreading along the axial wall). Data were analyzed using Kruskal-Wallis tests at the significance level of 0.05 . Results: Compared to $24 \mathrm{~h}$ storage, after thermocycling,

\section{RESUMO}

Objetivo: O objetivo deste estudo foi avaliar os padrões de microinfiltração de GIC e GGC com e sem seus revestimentos protetores superficiais nas margens de esmalte e dentina antes e após o envelhecimento. Material e Métodos: duas cavidades retangulares (altura: $2 \mathrm{~mm}$; largura: 3 $\mathrm{mm}$; profundidade: $1,5 \mathrm{~mm}$ ) foram preparadas em cada dente na junção cemento-esmalte de molares permanentes humanos $(\mathrm{N}=56)$, sendo aleatoriamente designados para serem restaurados com um dos seguintes: a) cimento de ionômero de vidro (GIC) de alta viscosidade (EQUIA Fil, C Corp., Tóquio, Japão) (n = 28), b) cimento de vidrocarbômero (GCC) Carbomer Products, Leiden, Holanda) (n $=28$ ). Metade dos dentes foram divididos em dois grupos, onde um grupo recebeu revestimento protetor de superfície (SC) (G-Coat Plus, GC Corp) ( $n=14)$ e o outro grupo não $(n=14)$. Metade dos dentes foram armazenados por 24 horas $(\mathrm{n}=7)$, e a outra metade foi termociclada (5000 ciclos, $\left.5-55^{\circ} \mathrm{C}\right)(\mathrm{n}=7)$. Para análise de microinfiltração, os dentes foram imersos em corante azul de metileno a $5 \%$ por 24 horas, seccionados em duas metades iguais. Os padrões de microinfiltração foram avaliados usando estereomicroscópio e pontuados numa escala de 0-3 (0: Sem penetração de corante; 1: penetração de corante inferior à metade da parede axial; 2: penetração de corante mais do que metade da parede axial; 3: penetração de corante ao longo da parede axial). Os dados foram analisados pelo teste de Kruskal-Wallis ao nível de significância de 0,05. Resultados: em comparação com o armazenamento de 24 h, após a termociclagem, o revestimento de superfície no GIC diminuiu significativamente a microinfiltração em 
surface coating on GIC decreased microleakage significantly compared to GCC $(\mathrm{p}=0.046)$ but not for GCC. In the thermocycled groups, coated GIC showed significantly less leakage at the enamel margin but no significant difference was found with both GIC and GCC in the dentin margins. Conclusion: The application of surface coating significantly reduced the microleakage scores of GIC but not GCC, within the enamel margins only.

\section{KEYWORDS}

Glass-carbomer; Glass-ionomer; Microleakage.

\section{INTRODUCTION}

$7 \Gamma$ he dental tissue loss restoration due to caries followed by filling the resulting cavity with an appropriate restorative material and sealing the margins in order to protect the tooth against possible microleakage and microbial attack. Microleakage is described as the movement of bacteria, liquid and chemical substances between the restoration and the tooth [1]. Results of such a leakage are usually discoloration of the restoration, margins or caries yielding to the failure of the restoration [2,3]. For this reason, microleakage patterns are important when selecting a restorative material [4].

In restorative dentistry, the objective is not only to remove the tooth tissues minimally and restore the cavity but also to expect therapeutic actions on the demineralized dentin. In this regard, glass ionomer cements (GIC) have been shown to have the potential to release and uptake of fluoride ions [5]. The major advantages of GIC include chemical adhesion to dentin and enamel, fluoride release, high tissue tolerance, and pulpal biocompatibility. On the contrary, inferior strength, abrasion resistance and poor aesthetics compared to resin-based materials are the limitations of GICs [6-8]. In 2007, a unique concept of highly viscous glassionomer material has been introduced (EQUIA Fil, GC Europe, Leuven, Belgium) which is self-adhesive, allows for bulk application with improved mechanical properties with a nano- comparação com o GCC (p = 0,046), mas não para o GCC. Nos grupos termociclados, o GIC revestido apresentou significativamente menos infiltração na margem do esmalte, mas não houve diferença significativa para o GIC e o GCC nas margens dentinárias. Conclusão: A aplicação do revestimento de superfície reduziu significativamente os escores de microinfiltração do GIC, mas não do GCC, apenas nas margens do esmalte.

\section{PALAVRAS-CHAVE}

Carbômero de vidro; Ionômero de vidro; Microinfiltração. filled composition. This high viscous GIC is then coated with photo-polymerizing varnish in order to provide protection in the early maturation phase for improved strength and surface hardness [9].

One other material for conventional GIC is glass carbomer cement (GCC) that contains fluorapatite particles at nano-size which was introduced in 2008. The only difference between clinical applications of GCC and conventional GICs is the heat application during the setting reaction. After setting, GCC also needs to be coated with a silicone-based coat to protect the surface from exposure to moisture and saliva during the first setting reaction and from dehydration in the second phase [10].

Microleakage properties of GIC and GCC with and without surface coatings have not been investigated. Therefore, the objective of this study was to evaluate the microleakage patterns of GIC and GGC with and without their protective surface coatings on enamel and dentin margins before and after aging. The null hypothesis tested was that GIC and GCC would not show significant difference in terms of microleakage with and without aging in all regions of the permanent teeth.

\section{MATERIALS AND METHODS}

\section{Specimen preparation}

Recently extracted human permanent molars without any fracture, caries, cracks or any 
deformities were selected for the study. Teeth were stored in in $0.5 \%$ Chloramin $\mathrm{T}$ at $5^{\circ} \mathrm{C}$ for 4 months until the experiments. Extractions were referreals to the Oral and Maxillofacial Surgery Department of Medipol University, Istanbul, Turkey, due to orthodontic reasons and patients (25 to 35 years of age) received written and verbal information that the teeth could be used for research purposes.

All the teeth $(\mathrm{N}=56)$ were cleaned with a brush and pumice/water slurry. Then, 2 rectangular cavities (Height: 2mm; Width: $3 \mathrm{~mm}$; Depth: $1.5 \mathrm{~mm}$ ) were prepared on each tooth at the cemento-enamel junction with a cylindrical diamond bur with a diameter of 0.8 $\mathrm{mm}$. The margins of the cavities were butt-joint being half located in the enamel and the other half in the root dentin. Cavities were prepared on human permanent molars $(\mathrm{N}=56)$ and the teeth were randomly assigned to be restored with one of the following ( $n=7 /$ each): a) high viscosity glass-ionomer cement (GIC) (EQUIA Fil, C Corp., Tokyo, Japan) $(n=28)$, b) glasscarbomer cement (GCC) (Glass Carbomer Products, Leiden, The Netherlands $(n=28)$. Half of the teeth were further divided into two groups where one group received protective surface coating (SC) (G-Coat Plus, GC Corp) $(n=14)$ and the other group not $(n=14)$. Half of the teeth were stored for $24 h(n=7)$, and the other half was thermocycled (5000 cycles, $\left.5-55^{\circ} \mathrm{C}\right)(\mathrm{n}=7)$.

The composite surface sealers used are listed in Table 1. All covering agents were applied according to the manufacturer's recommendations.

GIC (n:14): High viscosity glass-ionomer cement (EQUIA Fil, GC Corp., Tokyo, Japan) without SC.

GIC-SC (n:14): High viscosity glassionomer cement (EQUIA Fil) with SC (G-Coat Plus, GC Corp.).

GCC (n:14): Glass carbomer cement (GCP, Glass Carbomer Products, Leiden, Netherlands) without SC.

GCC-SC (n:14): Glass carbomer cement (GCP, Glass Carbomer Products) with SC (Glass Carbomer Surface Gloss, Glass Carbomer Products)
Chemical composition, types and the manufacturers of the materials used in the study are presented in Table 1.

All materials were handled and applied by one calibrated operator in strict accordance with each manufacturer's instructions. No cleaning and etching procedures wewre appolied for any of the material. After cavity preparation, GIC was mixed in an amalgamator for 10 s and applied to the cavities and polymerized (Coltolux 50, Coltene/Whaledent, NJ, USA). The output of the device was checked with a radiometer and assured an intensity of $480 \mathrm{~mW} / \mathrm{cm} 2$ during all the procedures. The GCC material was activated through photoactivation and the GIC through dual polymerization. After the specimens were incubated for $24 \mathrm{~h}$ at $37^{\circ} \mathrm{C}$, the restorations were finished with fine diamond burs and polished with abrasive disks (Soflex, 3M ESPE, St. Paul, MN, USA) under water spray.

Restoration surfaces were finished with a yellow band finishing bur (Meisinger, Neuss, Germany) under water cooling after $1 \mathrm{~min}$ and $30 \mathrm{~s}$ working time was completed. Finally, the corresponding SC (G-Coat Plus) was applied on the restoration surfaces and photo-polymerized with an LED unit (Elipar Freelight 2, 3M ESPE, St.Paul, MN, USA) for 20s according to the manufacturer's instructions.

For the GCC material, the capsule was activated, mixed for 15s (Rotomix, 3M ESPE, Seefeld, Germany), and extruded onto the tooth surface within $1 \mathrm{~min}$ from the start of mixing. For GCC group, no polishing procedures were performed. GCC was photo-polymerized using an LED device (CarboLED CL-02 lamp, $\geq 1500 \mathrm{~mW} / \mathrm{cm}^{2}$ ) for $20 \mathrm{~s}$.

Table 1 - Brands, abbreviations, chemical composition, types and manufacturers of the materials used in the study.

\begin{tabular}{cccc|} 
Brand & $\begin{array}{c}\text { Chemical Composition } \\
\text { Powder: } 95 \% \text { strontium fluoro- }\end{array}$ & Type & Manufacturer \\
$\begin{array}{c}\text { EQUIA } \\
\text { Fil (GIC) } \\
\text { aluminosilicate glass,5\% polyacrylic } \\
\text { acid. Liquid:50\% methyl metha- } \\
\text { crylate, } 0.09 \% \text { camphorquinone }\end{array}$ & $\begin{array}{c}\text { Glass- } \\
\text { ionomer }\end{array}$ & $\begin{array}{c}\text { GC Corp., } \\
\text { Tokyo, } \\
\text { Japan }\end{array}$ \\
$\begin{array}{cccc}\text { Glass- } \\
\text { carbo- } \\
\text { mer } \\
\text { (GCC) }\end{array}$ & $\begin{array}{c}\text { Fill: fluoro-aluminosilicateglass,apa- } \\
\text { tite, polyacids. Liquid: poly-acrylic } \\
\text { acid. loss: modified polysiloxanes }\end{array}$ & $\begin{array}{c}\text { Glass- } \\
\text { carbo- } \\
\text { mer }\end{array}$ & $\begin{array}{c}\text { merbo- } \\
\text { meducts, } \\
\text { Leiden, } \\
\text { The Nether- } \\
\text { lands }\end{array}$ \\
\hline
\end{tabular}




\section{Microleakage test}

All areas of the teeth were covered in two coats of acid-resistant nail polish, except the restoration and $1 \mathrm{~mm}$ rim around the tooth structure. The apices were sealed with sticky wax and the teeth were thermocycled. Thermocycling involved submerging the teeth for 10 s in water baths maintained between 5 and $55^{\circ} \mathrm{C}$ for $5000 \mathrm{c}$ ycles (Nova, Konya, Turkey), followed by rinsing under running water [10]. Each specimen was sectioned longitudinally in the middle using a diamond disc (Diamond Wafering Blade, Buehler, Lake Bluff, IL, USA) with a precision cutting machine (Isomet 1000, Buehler) under water cooling to attain two equal halves. The degree of marginal leakage was evaluated based on the penetration of the dye stain from the occlusal and gingival cavosurface margins to the base of the cavity preparation. Each specimen was viewed under a stereomicroscope (Olympus SZ61, Munster, Germany) at x30 magnification. Two independent pre-calibrated investigators independently examined the leakage scores. They blindly scored all interfaces and a consensus was reached in case of disagreement. The investigators scored microleakage according to the depth of dye penetration (Table 2) [10-14].

\section{Statistical analysis}

Statistical analysis was performed using Statistica 8.0 software for Windows (StatSoft, Inc., Tulsa, OK, USA). The data were analyzed using the Kolmogorov-Smirnov test for normal distribution. As the microleakage data obtained was not normally distributed, the nonparametric Kruskal-Wallis test was carried out at a significance level set at $\mathrm{p}<0.05$.

Table 2 - Description of dye penetration scores.

\begin{tabular}{|c|c|}
\hline Score & $\begin{array}{c}\text { Degree of dye penetration } \\
0\end{array}$ \\
\hline 1 & No dye penetration \\
\hline 2 & Dye penetration less than half the axial wall \\
\hline 3 & Dye penetration more than half the axial wall \\
\hline
\end{tabular}

\section{RESULTS}

The median, minimum and maximum microleakage values and significant differences are presented in Table 3.

Compared to $24 \mathrm{~h}$ storage, after thermocycling, at the enamel level, surface coating on GIC decreased microleakage significantly compared to GCC $(p=0.046)$, whereas on the dentin no significant difference was found between non-coated and coated groups ( $\mathrm{p}>0.05)$.

On the enamel level, thermocycling increased microleakage levels significantly compared to 24 water storage $(p=0.003)$ but on the dentin level, the difference was not significant $(p=0.075)$ being significantly worse than on enamel $(\mathrm{p}=0.002)$.

Porous surface of GCC was evident without and with surface coating (Figure 1a-1e).

Table 3 - The median, minimum and maximum microleakage values of the materials at enamel and dentin margins after $24 \mathrm{~h}$ and thermocycling $(p<0.05)$.

\begin{tabular}{|c|c|c|c|c|c|c|c|c|}
\hline \multirow{2}{*}{ Score } & \multirow{2}{*}{$\begin{array}{l}\text { Group } \\
\text { Degr }\end{array}$} & \multirow[b]{2}{*}{ Score } & \multirow{2}{*}{$\begin{array}{l}24 \mathrm{~h} \\
\text { Degr }\end{array}$} & \multicolumn{4}{|c|}{ Thermocycled } & \multirow{2}{*}{$\mathbf{P}$} \\
\hline & & & & Score & Degr & Score & Degr & \\
\hline \multirow{4}{*}{ Enamel } & GIC & 0 & 0 & 2 & 1 & 0 & 1 & 0.705 \\
\hline & GIC-SC & 2 & 1 & 3 & 1 & 1 & 2 & 0.046 \\
\hline & $\mathrm{GCC}$ & 2 & 1 & 2 & 1 & 1 & 2 & 0.655 \\
\hline & GCC-SC & 2 & 1 & 3 & 2 & 1 & 3 & 0.564 \\
\hline \multirow{4}{*}{ Dentin } & GIC & 1 & 0 & 2 & 1 & 0 & 2 & 0.334 \\
\hline & GIC-SC & 2 & 1 & 3 & 2 & 1 & 3 & 1.000 \\
\hline & GCC & 1 & 1 & 2 & 2 & 1 & 2 & 0.564 \\
\hline & GCC-SC & 3 & 2 & 3 & 2 & 1 & 3 & 0.257 \\
\hline
\end{tabular}




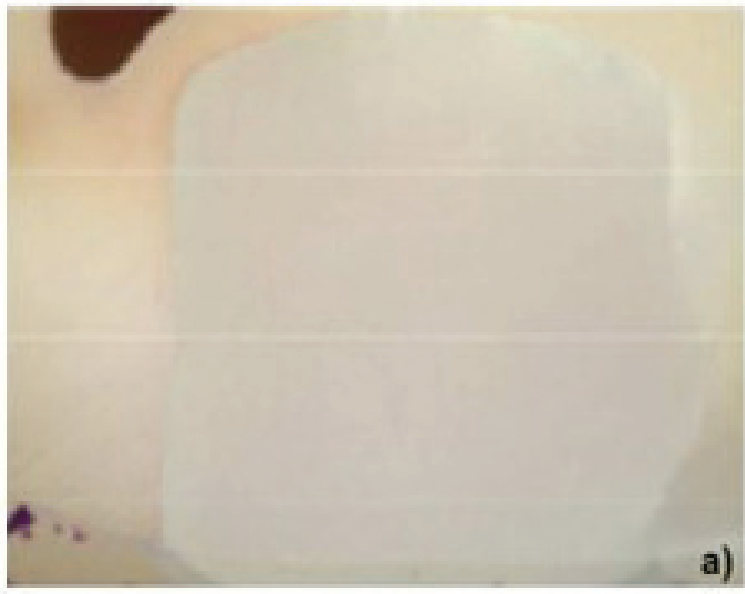

GIC-SC



GCC-SC

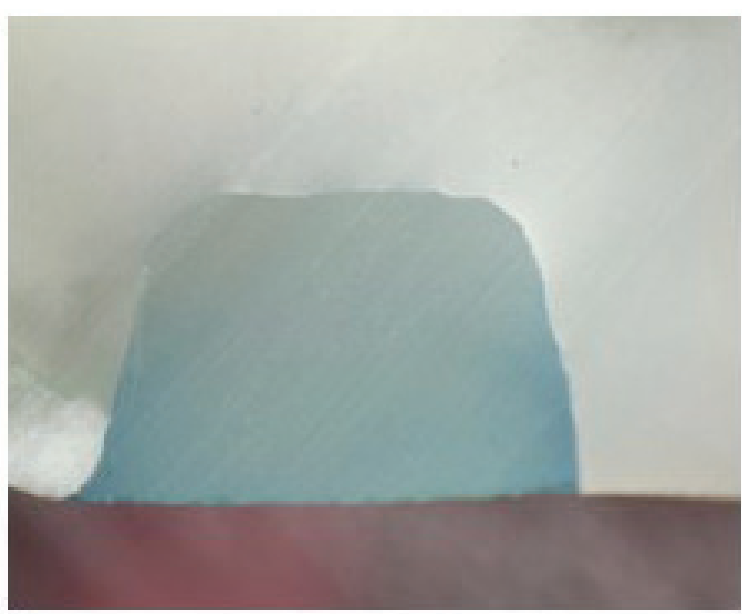

GCC

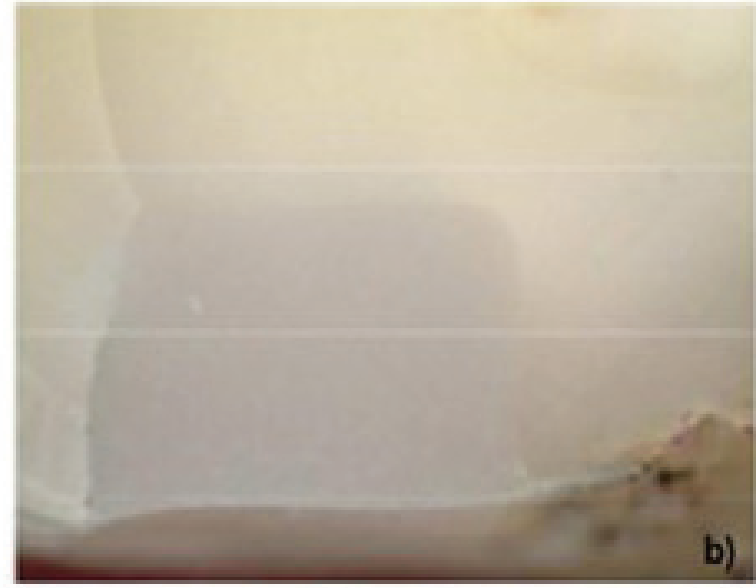

GIC

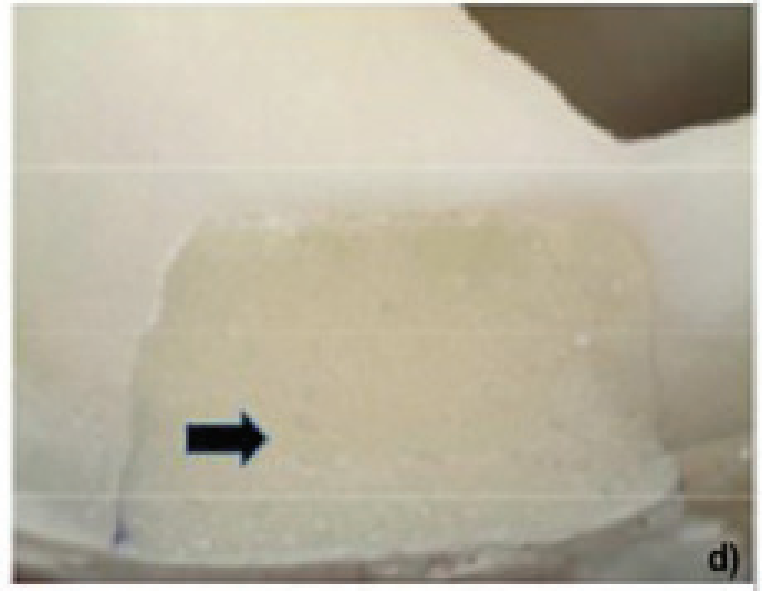

GCC SC (Score 2), d) GCC (Score 2), e) GCC (Score 3) (x30). Note the porous surface in c and d restored with GCC without and with surface coating indicated by arrow. For group abbreviations, see Table 1. 


\section{DISCUSSION}

This study was undertaken in order to evaluate the microleakage patterns of GIC and GCC with and without their protective surface coatings before and after aging at the restorative material-enamel and dentin margins. Since the material type and location showed significant difference, the null hypothesis could be rejected.

Microleakage is the one of the most common causes of failure of almost all restorative materials especially in the anterior region. Adaptation of dental restorative materials to the walls of cavities and the retentive ability of a material to seal the cavity against the ingress of oral fluids and microorganisms has always been of interest in dental restorations $[15,16]$. Although there is no strong evidence, this condition may cause hypersensitivity of restored tooth, tooth discoloration, recurrent caries, pulpal injury, and accelerated deterioration of the restorative material [17]. Accordingly, finding an ideal restorative material that has better adhesion characteristics could minimize microleakage, reducing the possible potential for caries development $[18,19]$.

The current study examined the microleakage patterns of glass-ionomer and glass-carbomer restorations placed in standard cavities in permanent teeth which were subjected to thermocycling. Thermocycling is a standard protocol applied in order to simulate aging of materials and interfaces in restorative literature when bonded materials are evaluated. Subjecting bonded materials to cyclic exposures of hot and cold conditions is affecred from the coefficient of thermal expansion of the tooth and the restorative material $[19,20]$. In fact, GIC presents similar thermal expansion coefficient with that of the tooth and therefore the results in enamel was superior. However, aging effect was evident with this material especially in dentin.

Decreased use of dental amalgam and increased demand for aesthetic restorations resulted in implementation of direct toothcoloured restorations in clinical dentistry. The most commonly used minimal invasive tooth- coloured restorative materials are typically resin composites and glass-ionomer cements [21]. One of the recommended options to improve the mechanical and physical properties of toothcoloured restorative materials is using surface protection similar to a self-adhesive coating. Infiltration of such self-adhesive coatings has been claimed to protect the material itself against crack initiation by filling the porosities, both of which could reinforce the materials, especially in the case of GICs. Its protective effect against extrinsic water may also allow complete maturation of the GIC reaction with delayed water exposure [22,23]. In this study, the specimens were not stored for $24 \mathrm{~h}$ before polishing and SC application. Therefore, sorption of liquids and interference between liquids and the materials tested could not be expected. As for the GCC product, in order to moisten the surface of the filling during modelling and to seal the restoration surface, the manufacturer provides a patented carbon silicon fluid, referred to as "Surface Gloss" [24].

In this study, for the first group, the least amount of dye leakage was observed in coated GIC in enamel and dentin margins. Coated GCC showed less microleakage than uncoated GCC in gingival dentin margin. Similarly, in the thermocycled groups, coated GIC showed the least leakage in the enamel margin only but no difference was found between the two materials in the dentin. The present results indicated that the absence of surface protection results in significant reductions in the marginal sealing features of both the conventional GIC and GCC at the early stage. However, after thermocycling, this effect was not observed and even some porosities were evident on surface coating of GCC which is most probably due to water absorption during thermocycling.

The relationship between marginal leakage in restorations and the type of restorative materials has been extensively studied in both laboratory and clinical studies. The methods that are available to evaluate microleakage include direct visual examination $[25,26]$, microscopic examination [27,28], 
scanning electron microscopic examination [2931], air pressure,[32], dye penetration [33-36], the use of a chemical tracer $[37,38]$, the use of radioactive isotope tracer [39-41], neutron activation analysis [42], electrochemical methodologies [43], measuring bacteria penetration [44], the artificial caries method [45] and three-dimensional image analysis [46]. The most employed method among all of these methods is still quantifying migration of dye penetration along the tooth/restoration interface $[47,48]$. In addition to this, dye penetration method may also be useful for predicting the performance of restorative materials and marginal gap appendage throughout the axial wall of the restorations $[49,50]$. Hence, the same method of dye penetration was employed in the present study utilizing methylene blue as the dye material. Yet, microleakage with this method remains to be non-quantitative which could still be considered as a subjective method and considered as a limitation of such studies, including this one.

The results obtained in this study showed that the materials that were investigated exhibited no difference in microleakage. Y1k1lgan et al. [51] evaluated the microleakage performance of high viscosity GIC similar to this study and reported that this material shows similar clinical properties compared to those of the resin composites in class $\mathrm{V}$ restorations. In this study, however, GIC was superior to GCC only in the enamel margins. Thus, both materials tested may suffer from increased microleakage in the dentin region when exposed to aging. In another study, Shurithi et al. [19] evaluated the microleakage among conventional, resin modified GIC and compomer cements in primary teeth and concluded that none of the three materials was free from microleakage which is in accordance with the findings of the present study. Further research should focus on the development of more stable surface coatings for both GIC and GCC tested.

\section{CONCLUSION}

From this study, the following conclusions were drawn:

1- The application of surface coating significantly reduced the microleakage scores of high viscosity glass-ionomer compared to glass carbomer cement at the enamel-restoration margins.

2- Application of surface coating did not decrease the microleakage at restoration-dentin interface with both materials tested.

\section{Conflict of interest}

The authors did not have any commercial interest in any of the materials used in this study.

\section{REFERENCES}

1. Bauer JG, Henson JL. Microleakage: a measure of the performance of direct filling materials. Oper Dent. 1984 Winter;9(1):2-9.

2. Brannstrom M, Nordenvall KJ. Bacterial penetration, pulpal reaction and the inner surface of Concise enamel bond. Composite fillings in etched and unetched cavities. J Dent Res. 1978 Jan;57(1):3-10.

3. Varpio M, Warfvinge J, Noren JG. Proximo-occlusal composite restorations in primary molars- marginal adaptation. Bacterial penetration and pulpal reactions. Acta Odontol Scand. 1990 Jun;48(3):161-7.

4. Shih WY. Microleakage in different primary tooth restorations. JChin Med Assoc. 2016 Apr;79(4):228-34. doi: 10.1016/j.jcma.2015.10.007. Epub2016 Feb1.

5. Friedl K, Hiller KA, Friedl KH. Clinical performance of a new glass ionomer based restoration system: a retrospective cohort study. Dent Mater. 2011 0ct;27(10):1031-7. doi: 10.1016/j.dental.2011.07.004. Epub 2011 Aug 15.

6. Cefaly DF, Valarelli FP, Seabra BG, Mondelli RF, Navarro MF. Effect of time on the diametral tensile strength of resin-modified restorative glass ionomer cements and compomer. Braz Dent J. 2001;12:201-4.

7. Castro A, Feigal RE. Microleakage of a new improved glass ionomer restorative material in primary and permanent teeth. Pediatr Dent. 2002 Jan-Feb;24(1):23-8.

8. Scholtanus JD, Huysmans MC. Clinical failure of class-II restorations of a highly viscous glass-ionomer material over a 6 -year period: a retrospective study. J Dent. 2007 Feb;35(2):156-62. Epub 2006 Sep 14.

9. Kato K, Yarimizu H, Nakaseko H, Sakuma T. Influence of coating materials on conventional glass-ionomer cement. http://iadr.confex.com/iadr/search. epl;2008.

10. Demirci M, Tuncer S, Tekçe N, Erdilek D, Uysal Ö. Influence of adhesive application methods and rebonding agent application on sealing effectiveness of all-in-one self-etching adhesives. J Esthet Restor Dent. 2013 Oct;25(5):326-43. doi: 10.1111/jerd.12034. Epub 2013 May 15. 
11. Osorio R, Toledano M, de Leonardi G, Tay F. Microleakage and interfacial morphology of selfetching adhesives in class $V$ resin composite restorations. J Biomed Mater Res B Appl Biomater. 2003 Jul 15;66(1):399-409.

12. Hussein TA, Bakar WZ, Ghani ZA, Mohamad D. The assessment of surface roughness and microleakage of eroded tooth-colored dental restorative materials. J Conserv Dent. 2014 Nov;17(6):531-5. doi: 10.4103/09720707.144585 .

13. Hepdeniz OK, Temel UB, Ugurlu M, Koskan 0. The effect of surface sealants with different filler content on microleakage of Class $V$ resin composite restorations. Eur J Dent. 2016 Apr-Jun;10(2):163-9. doi:10.4103/13057456.178315 .

14. Özsoy A, Eren MM, Gürbüz Ö, Dikmen B, Cilingir A, Erdemir E. Effect of desensitizers on the microleakage of previously restored Class $V$ resin composite restorations. J Adhes Sci Technol. 2016;4:1-11. doi: 10.1080/01694243.2016.1177319.

15. Mali P,Deshpande S, Singh A. Microleakage of restorative materials: An in vitro study. J Indian Soc Pedod Prev Dent. 2006 Mar;24(1):15-8.

16. Abd El Halim S, Zaki D. Comparative evaluation of microleakage among three different glass ionomer types. Oper Dent. 2011 Jan-Feb;36(1):36-42. doi: 10.2341/10-123-LR. Epub 2011 Mar 24.

17. Upadhyay S, Rao A. Nanoionomer: Evaluation of microleakage. J Indian Soc Pedod Prev Dent. 2011 Jan-Mar;29(1):20-4. doi: 10.4103/0970-4388.79919.

18. Castro A, Feigal RE. Microleakage of a new improved glass ionomer restorative material in primary and permanent teeth. Pediatr Dent. 2002 Jan-Feb;24(1):23-8.

19. Shruthi AS, Nagaveni NB, Poornima P, Selvamani M, Madhushankari GS, Subba Reddy VV. Comparative evaluation of microleakage of conventional and modifications of glass ionomer cement in primary teeth: An in vitro study. J Indian Soc Pedod Prev Dent. 2015 0ct-Dec;33(4):279-84. doi: 10.4103/0970-4388.165662

20. Nalcaci A, Ulusoy N. Effect of thermocycling on microleakage of resin composites polymerized with LED curing techniques. Quintessence Int 2007 Jul-Aug;38(7):e433-9.

21. Cramer NB, Stansbury JW, Bowman CN. Recent advances and developments in composite dental restorative materials. J Dent Res. 2011 Apr;90(4):402-16. doi: 10.1177/0022034510381263. Epub 20100 ct5.

22. Roberts HW, Berzins DW, Charlton DG. Hardness of three resin-modified glass-ionomer restorative materials as a function of depth and time.J Esthet Restor Dent. 2009;21(4):262-72. doi: 10.1111//.1708-8240.2009.00273.x.

23. Bagheri R, Palamara JE, Mese A, Manton DJ. The effect of a self-adhesive coating on the load bearing capacity of tooth-colored restorative materials. Aust Dent J. 2017 Mar;62(1):71-78. doi:10.1111/adj.12432. Epub 2016 Dec 28.

24. Cehreli SB, Tirali RE, YalcinkayaZ, Cehreli ZC. Microleakage of newly developed glass carbomer cement in primary teeth. Eur J Dent. 2013 Jan; $7(1): 15-21$.

25. Nelsen RJ, Wolcott RB, Paffenbarger GC. Fluid exchange at the margins of dental restorations. J Am Dent Assoc. 1952 Mar;44(3):288-95.

26. Cvar JF, Ryge G. Criteria for the clinical evaluation of dental restorative materials. San Francisco: United States Department of Health, Education and Welfare; 1971
27. Saltzberg DS, Ceravolo FJ, Holstein F, Groom G, Gottsegen R. Scanning electron microscope study of the junction between restorations and gingival cavosurface margins. J Prosthet Dent. 1976 Nov;36(5):517-22.

28. Jodaikin A, Grossman ES. Experimental marginal leakage around dental amalgams placed in artificial cavities. J Dent Res. 1984 Aug;63(8):1090-2.

29. Grundy JR. An intra-oral replica technique for use with the scanning electron microscope. Br Dent J. 1971Feb 2;130(3):113-7.

30. Hicks MJ, Flaitz CM, Silverstone LM. Secondary caries formation in vitro around glass ionomer restorations. Quintessence Int. 1986 Sep;17(9):527-32.

31. Davila JM, Gwinnett AJ, Robles JC. Marginal adaptation of composite resins and dentinal bonding agents. ASDC J Dent Child. 1988 Jan-Feb;55(1):25-8.

32. Barnes IE. Replica models for the scanning electron microscope. Br Dent $\mathrm{J}$ 19720ct 17;133(8):337-42.

33. Fanian F, Hadavi F, Asgar K. Marginal leakage of dental amalgam. Oper Dent. 1983 Winter:8(1):11-7.

34. Guelmann M, Fuks AB, Holan G, Grajower R. Marginal leakage of class II glass-ionomer-silver restorations with and without posterior composite coveragedan in vitro study. ASDC J Dent Child. 1989 Jul-Aug:56(4):277-82.

35. Chan CC, Lin TH, Chan KW, Chung KH. Assessment of microleakage of cervical restorations. J Chin Med Assoc. 2005 Jul;68(7):299-306.

36. Ovrebö RC, Raadal M.. Microleakage in fissures sealed with resin or glass ionomer cement. Scand J Dent Res. 1990 Feb;98(1):66-9.

37. Douglas WH, Fields RR, Fundingsland J. A comparison between the microleakage of direct and indirect composite restorative system. J Dent. 1989 Aug;17(4):184-8.

38. Taylor MJ, Lynch E. Microleakage.J Jent. 1992 Feb;20(1):3-10.

39. Gottlieb EN, Retief DH, Bradley EL. Microleakage of conventional and highcopper amalgam restorations. J Prosthet Dent. 1985 Mar;53(3):355-61.

40. Hammesfahr PH, Huang CT, Shaffer SE. Microleakage and bond strength of resin restorations with various bonding agents. Dent Mater. 1987 Aug;3(4):194-9

41. Fitchie JG, Reeves OW, Scarbrough AR, Hembree JH. Microleakage of two new dentinal bonding systems. Quintessence Int. 1990 Sep;21(9):749-52.

42. Herrin HK, Shen C. Microleakage of root caries restorations. Gerodontics. 1985 Aug;1(4):156-9.

43. Going RE, Myers HM, Prussin SG. Quantitative method for studying microleakage in vivo and in vitro. J J Dent Res. 1968 Nov-Dec;47(6):1128-32.

44. Momoi Y, Iwase H, Nakano Y, Kohno A, Asanuma A, Yanagisawa K. Gradual increases in marginal leakage of resin composite restorations with thermal stress. JDent Res. 1990 0ct:69(10):1659-63.

45. Mejare B, Mejare I,Edwardsson. Bacteria beneath composite restorationsda culturing and histobacteriological study. Acta Odontol Scand. 1979;37(5):267-75.

46. Youngson CC. A technique for three-dimensional microleakage assessment using tooth sections. J Dent. 1992 Aug;20(4):231-4. 
47. Alani $A H$, Toh CG. Detection of microleakage around dental restorations: a review. Oper Dent. 1997 Jul-Aug;22(4):173-85.

48. Raskin Ai D'Hoore W, Gonthier S, Degrange M, et al. Reliability of in vitro microleakage tests: a literature review. J Adhes Dent. 2001 Winter:3(4):295-308.

49. Hepdeniz OK, Temel UB, Ugurlu M, Koskan 0. The effect of surface sealants with different filler content on microleakage of Class V resin composite restorations. Eur J Dent. 2016 Apr-Jun;10(2):163-9. doi: 10.4103/13057456.178315 .
50. Ernst CP, Galler P,Willershausen B, Haller B. Marginal integrity of class V restorations: SEM versus dye penetration. Dent Mater. 2008 Mar;24(3):31927. Epub 2007 Jul31.

51. Yikilgan İ,Akgul S, Özcan S, Bala 0, Ömürlü H. An in vitro evaluation of the effects of desensitizing agents on microleakage of Class V cavities. J Clin Exp Dent. 2016 Feb 1;8(1):e55-9. doi: 10.4317/jced.52755. eCollection 2016 Feb.

\section{Assist. Prof. Dr. Aslı Patır Münevveroğlı}

(Corresponding address)

Istanbul Medipol University, Department of Pedodontics, School of Dentistry,

Unkapanı, Atatürk Bulvarı, No:27, Fatih 34083, Istanbul, Turkey.

Tel:+90-212-453-4848; Fax: +90-212-521-0426.

Date submitted: 2018 Jul 24

E-mail: apatir@medipol.edu.tr

Accept submission: 2018 Jan 21 